\title{
Analisis Perbandingan Pemodelan Pathloss COST-231 Hata dan Walfisch Ikegami Terhadap Pathloss Pengukuran dengan Metode Drive Test di Wilayah Banyumas
}

\author{
Muntaqo Alfin Amanaf ${ }^{1}$, Achmad Rizal Danisya ${ }^{2}$, Robi Rodian ${ }^{3}$ \\ 1,2,3 Institut Teknologi Telkom Purwokerto \\ 1,2,3J1. D.I Panjaitan No.128 Purwokerto, Jawa Tengah, Indonesia \\ Email korespondensi : muntaqo@st3telkom.ac.id
}

Dikirimkan 21 Agustus 2017, Direvisi 28 September 2017, Diterima 17 Oktober 2017

\begin{abstract}
Abstrak - Pemodelan pathloss adalah komponen penting dalam perancangan jaringan komunikasi wireless. Pemodelan pathloss ini membantu memprediksi seberapa buruk pathloss atau redaman yang terjadi pada area perencanaan jaringan komunikasi wireless. Dalam memprediksi pathloss diperlukan pemilihan beberapa pemodelan pathloss yang sesuai dengan karakterisik wilayah tertentu agar pada saat implementasi jaringan wireless, jaringan tersebut dapat memberikan layanan komunikasi wireless yang optimal sesuai dengan hasil perancangan. Pada penelitian ini dibandingkan pemodelan pathloss COST-231 Hata dan pathloss Walfisch Ikegami terhadap pathloss Pengukuran di wilayah Banyumas untuk memilih pemodelan pathloss yang sesuai dengan karakteristik wilayah Banyumas di tiap cluster Urban, Sub-Urban, dan Rural. Pathloss pengukuran diperoleh melalui pengukuran daya terima handphone dengan metode drive test pada frekuensi $1800 \mathrm{MHz}$. Grafik pathloss dan nilai MSE (Mean Square Error) dari pathloss pengukuran dianalisis terhadap masingmasing pemodelan pathloss di tiap cluster. Hasil pada penelitian ini, pemodelan pathloss COST-231 cluster Urban dan Rural mempunyai kesesuaian dengan pathloss pengukuran dengan nilai MSE adalah 18,16 dB dan 10,33 dB,sedangkan pada cluster Sub-Urban mempunyai kesesuaian dengan pathloss Walfisch Ikegami dengan nilai MSE 5,58 dB.
\end{abstract}

Kata kunci - COST-231 Hata,Walfisch Ikegami, DriveTest, Pathloss, MSE

Abstract - The Pathloss model is an important component for wireless communication network planning. This Pathloss model can predict how bad the path loss that occurs in the wireless communication network planning area. Predicting the pathloss need the selection of some pathloss model according the characteristic of the certain area so that when the implementation of wireless networks, the network can provide optimal wireless communication services as the planning result.In this study pathloss model COST-231 Hata and Pathloss Model Walfisch Ikegami are compared to Pathloss Measurements in Banyumas Area for selecting which Pathloss model that corresponds to the characteristics of banyumas region in each Urban, Sub-Urban and Rural Cluster. Pathloss measurement is obtained by measuring the received power of mobile phones with the Drive test method at a frequency of $1800 \mathrm{MHz}$. The pathloss graph and MSE (Mean Square Error) from Pathloss Measurement are analyzed by Pathloss model in each Cluster. The results of this study, Pathloss COST-231 Urban and Rural Pathloss model had compatibility with Pathloss measurement by MSE value are $18.16 \mathrm{~dB}$ and $10.33 \mathrm{~dB}$, while in the Sub-Urban Cluster had compatibility with Pathloss Walfisch Ikegami with MSE value $5.58 \mathrm{~dB}$.

Keywords - COST-231 Hata, Walfisch Ikegami, Drivetest, Pathloss, MSE

\section{PENDAHULUAN}

Pathloss merupakan redaman yang mengakibatkan pengurangan atau penurunan nilai daya terima gelombang elektromagnetik karena melewati udara maupun kanal wireless. Nilai pathloss ini dipengaruhi oleh kontur tanah, lingkungan (perkotaan atau pedesaan, vegetasi, dan dedaunan), media propagasi 
(udara kering atau lembab), jarak antara pemancar dan penerima, ketinggian, dan lokasi antenna [1]. Pathloss ini merupakan salah satu komponen utama dalam analisis dan perancangan linkbudget dari suatu sistem telekomunikasi [2]. Model pathloss dapat diklasifikasikan ke dalam dua model kategori utama, yaitu model empiris dan model deterministik. Model empiris didasarkan pada data yang diukur secara praktis. Kelebihan model ini menggunakan parameterparameter sederhana tetapi kelemahannya tidak terlalu akurat untuk wilayah tertentu. Model yang dikategorikan sebagai model empiris untuk lingkungan makro seluler adalah model Okumura dan model COST-231 Hatta. Di sisi lain model deterministik sangat akurat tetapi parameter yang digunakan sangat banyak, cukup rumit, detil, dan butuh pemetaan. Beberapa contoh model pathloss deterministik adalah model Walfisch Ikegami dan Ray Tracing. Semua model tersebut memperkirakan rata-rata pathloss berdasarkan beberapa parameter seperti tinggi antena pemancar (base transceiver station) dan penerima (mobile station), jarak antara keduanya, tinggi gedung penghalang, arah jalan dan lain-lain. Model ini telah divalidasi secara luas untuk jaringan mobile. Selain itu sebagian besar model tersebut didasarkan pada interpretasi sistematis terhadap data pengukuran yang diperoleh di area layanan tertentu [3]. Oleh karena itu pada penelitian ini mengambil perbandingan dari dua kategori pemodelan yaitu dari kategori empiris adalan model pathloss COST-231 Hata sedangkan dari kategori deterministik adalah model pathloss Walfisch Ikegami.

Pada penelitian [4] sebelumnya telah dikaji tentang pemilihan beberapa pemodelan pathloss secara simulasi dengan pemodelan pathloss Okumura Hata, COST-231 Hata dan Walfisch Ikegami untuk teknologi LTE dengan hasil kedua pemodelan tersebut bisa digunakan untuk memodelkan pathloss di teknologi LTE. Sedangkan pada penelitian [5] mengkaji pemodelan pathloss untuk LTE Advanced di frekuensi 2,4 Ghz, 2,6 GHz dan 3,5 GHz dengan menggunakan pemodelan pathloss SUI, COST231Hata dan Walfisch Ikegami. Pada penelitian tersebut menyimpulkan pemodelan pathloss COST231 Hata mempunyai nilai pathloss terkecil untuk semua area Urban, Sub-Urban, dan Rural. Pada penelitian [6] membandingkan pathloss model COST231 Hata, Okumura Hata,dan Hata Davidson model untuk aplikasi broadcasting di India, hasil pada penelitian tersebut COST-231 Hata memiliki nilai MSE (Mean Square Error) paling kecil dibandingkan pathloss model lainnya. Di Indonesia pada penelitian telah dilakukan pengukuran drive test di Padang tetapi hanya menggunakan satu pemodelan pathloss yaitu pathloss Okumura Hata pada teknologi GSM [7]. Sedangkan pada penelitian ini menggunakan dua pathloss pemodelan yaitu model COST-231 Hata dan model Walfisch Ikegami untuk dibandingkan terhadap pathloss pengukuran di wilayah Banyumas, hal ini dapat digunakan untuk memilih pemodelan pathloss mana yang lebih sesuai dengan karakteristik wilayah Banyumas.

\section{METODE PENELITIAN}

Pada penelitian ini perlu dilakukan beberapa langkah yang ditampilkan pada Gambar 1 .

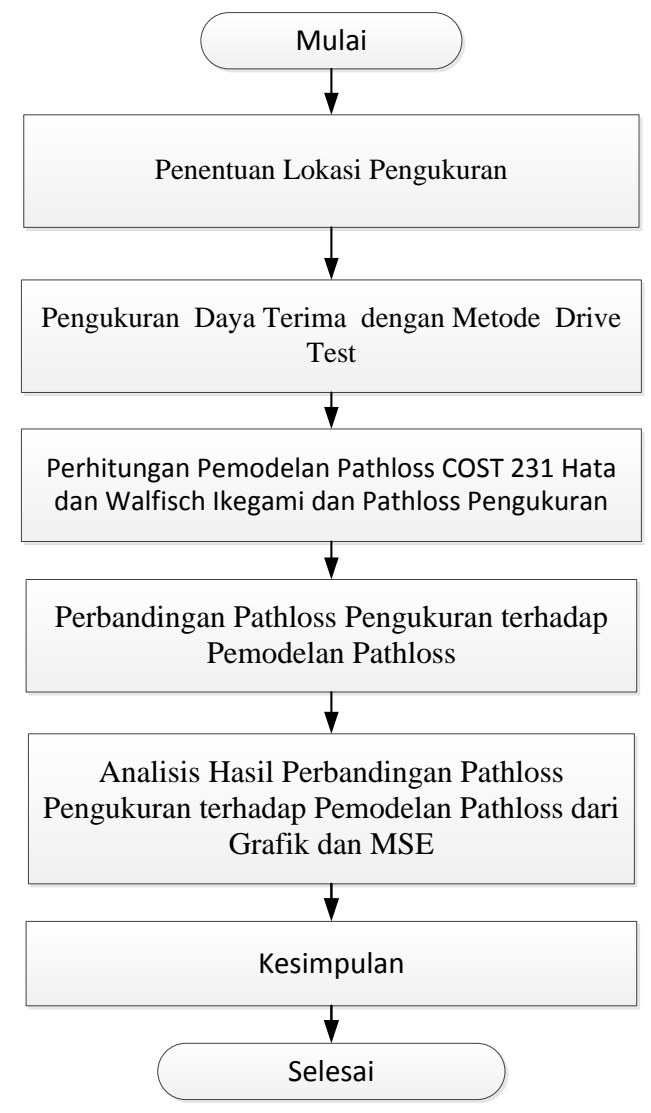

Gambar 1. Diagram Alir Penelitian

\section{A. Penentuan Lokasi Pengukuran}

Pada penelitian ini terlebih dahulu ditentukan titik lokasi pengukuran dari tiap cluster Urban, Sub-Urban, dan Rural. Pada cluster urban di tentukan di daerah purwokerto dengan karakterisitk daerah perkotaan dengan kepadatan penduduk tinggi serta terdapatgedung-gedung perkantoran yang tinggi. Pada cluster Sub-Urban dipilih daerah rempoah dengan karakteristik Sub-Urban berupa daerah perumahan dengan kepadatan penduduk rendah. Terakhir pada cluster Rural ditentukan di daerah Kedungrandu dengan karakteristik daerah lingkungan sawah dan padang rumput serta kepadatan penduduk yang sangat rendah. Informasi tentang lokasi pengukuran dapat dilihat pada Tabel 1 .

Tabel 1. Lokasi Pengukuran Daya Terima

\begin{tabular}{ccccc}
\hline No & Cluster & Longitude & Latitude & $\begin{array}{c}\text { Nama } \\
\text { Daerah }\end{array}$ \\
\hline 1 & Urban & 109.23725 & -7.4243611 & Purwokerto \\
2 & $\begin{array}{c}\text { Sub- } \\
\text { Urban }\end{array}$ & 109.23419 & -7.3450833 & Rempoah \\
3 & Rural & 109.21936 & -7.4677222 & Kedungrandu \\
\hline
\end{tabular}




\section{B. Pengukuran Daya Terima dengan Drive Test}

Pada penelitian ini dilakukan pengambilan data menggunakan metode drive test. Drive test merupakan salah satu metode yang bertujuan untuk mengambil maupun mengumpulkan informasi maupun data kualitas sinyal user pada saat menggunakan perangkat telekomunikasi secara langsung. Metode drive test digunakan untuk mengukur kualitas sinyal dan memperbaiki masalah yang berhubungan dengan sinyal yang dipancarkan BTS. Dalam drive test, MS (Handphone) akan bergerak (mobile) untuk mengukur daya pancar dari BTS agar dapat diketahui di daerah mana saja yang tercakupi oleh sinyal dari suatu BTS [8].

Proses pengukuran daya terima dengan metode Drive test ini membutuhkan beberapa peralatan yang berupa handphone, GPS (Global Positioning System), laptop beserta software drive test (TEMS/Nemo /Agilent), map digital serta rencana rute perjalanan pengukuran seperti ditunjukkan pada Gambar 2 [9].

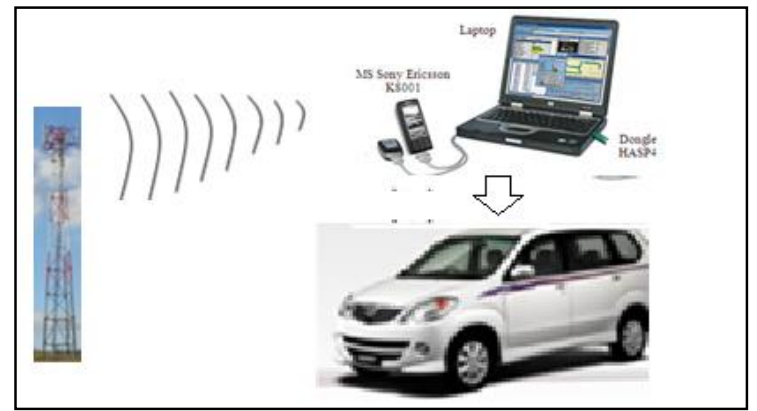

Gambar 2. Set-Up Pengukuran Daya Terima Dengan Metode Drive Test

Pengukuran daya terima dengan metode drive test dilakukan dengan mengukur level daya yang diterima Mobile Station (MS) yang bergerak mendekati dan menjauhi BTS dari jarak $0,1 \mathrm{~km}$ sampai dengan $2 \mathrm{~km}$ dengan jarak antar titik sejauh $0,1 \mathrm{~km}$ seperti pada Gambar 3. Jarak pengukuran diperoleh berdasarkan posisi garis lintang bujur dari GPS sedangkan jumlah sample data diambil berdasarkan pada jarak $0,1 \mathrm{~km}$ sampai $2 \mathrm{~km}$ dari BTS Existing. Parameter yang diperlukan dalam pengukuran adalah daya terima dengan fungsi jarak.

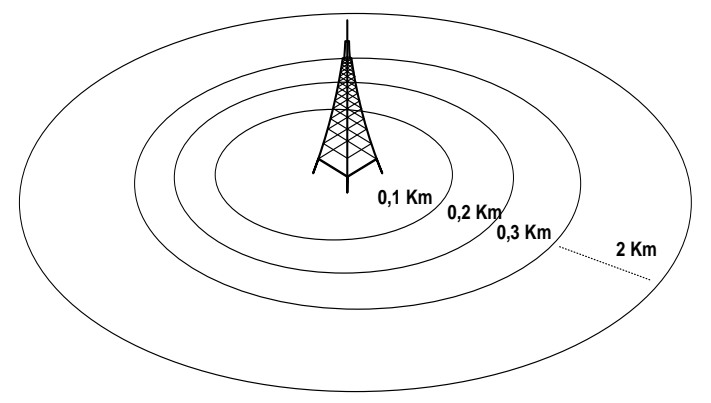

Gambar 3.Skenario Pengukuran Daya Terima.

\section{Pemodelan Pathloss COST-231 Hata}

Pemodelan pathloss COST- 231 Hata merupakan hasil pengembangan dari pemodelan pathloss sebelumnya yaitu pathloss Okumura Hata. Pemodelan ini memiliki spesifikasi frekuensi kerja dari 1500 hingga $2000 \mathrm{MHz}$ serta tinggi antenna Base Station dan Mobile Station tertentu sesuai Tabel 2 [10].

Tabel 2. Spesifikasi Parameter yang Berlaku Pada Model COST$231[10]$

\begin{tabular}{ccc}
\hline Parameter & Notasi & Spesifikasi \\
\hline Frekuensi Pembawa & $\mathrm{F}$ & $1500-2000 \mathrm{MHz}$ \\
Tinggi Antena BTS & $\mathrm{hB}$ & $4-50 \mathrm{~m}$ \\
Tinggi Antena Ms & $\mathrm{Hm}$ & $1-3 \mathrm{~m}$ \\
Jarak BTS dengan Ms & $\mathrm{D}$ & $0.02-5 \mathrm{~km}$ \\
\hline
\end{tabular}

Sedangkan persamaan dari COST-231 Hata adalah sebagai berikut

$\mathrm{Lp}=46,3+(44,9-6,55 \log \mathrm{Hb}) \log d+33,9(\log \mathrm{f})+\mathrm{cm}-13,82$ $\log (\mathrm{hm})-\mathrm{a}(\mathrm{hm})$

Untuk area Urban

$\mathrm{a}(\mathrm{hm})=-4,97+3,2(\log 11,75 \mathrm{hm})^{2}$

Untuk area Sub-Urban dan Rural :

$\mathrm{a}(\mathrm{hm})=(1,1 \log \mathrm{f}-0,7) \mathrm{hm}-(1,56 \log \mathrm{f}-0,8)$

Keterangan :

f = Frekuensi dari $1500 \mathrm{MHz}$ sampai dengan 2000 $\mathrm{MHz}$

$\mathrm{Hb}=$ Tinggi antenaBTS

$\mathrm{hm}=$ Tinggi antena MS/Handphone

$\mathrm{d}=$ Jarak antara base station dengan mobile station $\mathrm{a}(\mathrm{hm})=$ Faktor koreksi untuk tinggi efektif antena

$\mathrm{cm}=0 \mathrm{~dB}$ untuk ukuran medium kota dan daerah Sub-Urban

$\mathrm{cm}=3 \mathrm{~dB}$ untuk daerah pusat kota

Tabel 3. Parameter Penelitian Pemodelan Pathloss COST-231

\begin{tabular}{cccc}
\hline No & Notasi & Satuan & Nilai \\
\hline \multirow{2}{*}{1} & & & 37 (Urban) \\
& $\mathrm{Hb}$ & Meter $(\mathrm{m})$ & 65 (Sub-Urban) \\
2 & $\mathrm{Hm}$ & Meter $(\mathrm{m})$ & 68 (Rural) \\
3 & $\mathrm{~d}$ & Kilometer $(\mathrm{Km})$ & 1,5 \\
4 & $\mathrm{Fc}$ & Mhz & $0,1-2$ \\
\hline
\end{tabular}

\section{Pemodelan Pathloss Walfisch Ikegami}

Model propagasi ini merupakan pemodelan untuk memodelkan area outdoor dan digunakan pada frekuensi $800 \mathrm{MHz}$ sampai $2000 \mathrm{MHz}$. persamaannya sebagai berikut [11]. 


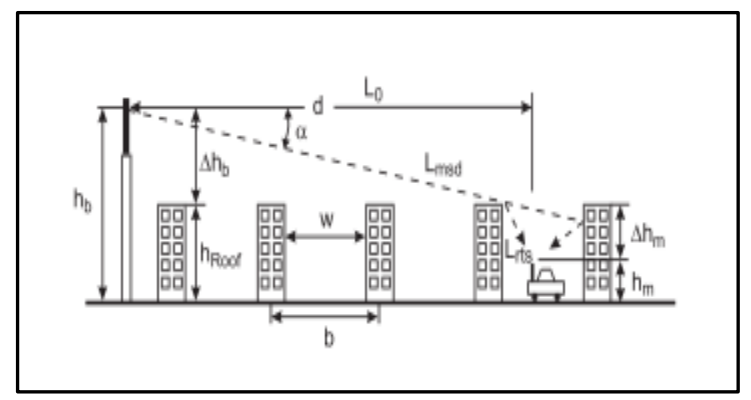

Gambar 4. Ilustrasi Parameter-Parameter Pada Model Pathloss Walfisch Ikegami [11]

Persamaan dengan kondisi LOS (Line of Sight) adalah

$\mathrm{PL}=26 \log \mathrm{d}+20 \log \mathrm{fc}+42,6$

Untuk Kondisi NLOS (Non-Line of Sight) adalah

$\mathrm{PL}=\mathrm{PLo}+\mathrm{Lmsd}+\mathrm{Lrts} \quad$ untuk Lrts + Lmsd $>0$

$\mathrm{PL}=\mathrm{PLo} \quad$ untuk Lrts + Lmsd $\leqslant 0$

Sedangkan Persamaan free space pathloss adalah PLo $=20 \log d+20 \log f c+32,4$

Nilai rugi-rugi difraksi pada Walfisch Ikegami berasal dari rumus Lrts dengan persamaan sebagai berikut

Lrts $=-16,9 \mathrm{w}+10 \log \mathrm{fc}-10 \log +20 \log \Delta \mathrm{hm}+$ Lori $(8)$

$\Delta \mathrm{hm}=$ hroof $-\mathrm{hm}$

$\Delta \mathrm{hm}$ adalah selisih antara tinggi bangunan/penghalang (hroof) dan tinggi MS penerima $(\mathrm{hm})$. Arah sudut jalan diperhitungkan oleh faktor koreksi empiris (Lori) yaitu

$\begin{array}{lll}\mathrm{L} \text { ori }=-10+0,354 \varphi & \text { untuk } & 0 \leq \varphi<35^{0} \\ 2,5+0,075(\varphi-350) & \text { untuk } & 350 \leq \varphi<550^{\circ} \\ 4-0,114(\varphi-550) & \text { untuk } & 550 \leq \varphi<900^{\circ}\end{array}$

Lmsd $=$ Lbsh $+k a+k d \log (d)+k f \log (f)-9 \log (b)$

Lbsh $=-18 \log (1+\Delta h b) \quad$ untuk hb> hroof

0 untuk $\mathrm{hb} \leq \mathrm{hroof}$

$\mathrm{Ka}=54 \quad$ untuk hb> hroof

$54-0,8 \Delta \mathrm{hb} \quad$ untuk $\mathrm{d} \geq 0,5 \mathrm{~km}$ dan $\mathrm{hb} \leq$ hroof

$54-0,8 \Delta \mathrm{hbd} / 0,5$ untuk $\mathrm{d}<0,5 \mathrm{~km}$ dan $\mathrm{hb} \leq$ hroof

Dimana

$\Delta \mathrm{hb}=\mathrm{hb}$ - hroof

$\mathrm{Kd}=18$

$18-5 \Delta \mathrm{hb} / \mathrm{hroof}$

untuk hb> hroof

untuk $\mathrm{hb} \leq$ hroof

$\mathrm{Kf}=-4+0,7(\mathrm{fc} / 925)-1$ (Untuk kota ukuran menengah)

$-4+1,5(\mathrm{fc} / 925)-1$ (Untuk kota metropolitan)

Keterangan :

PL = Pathloss/Rugi-rugi redaman propagasi

PLo = Free space pathloss

Lrts = Rugi rugi dari atap ke jalan

Lmsd = Rugi rugi difraksi multi screen

Lori $=$ Faktor koreksi empiris

$\mathrm{f} \quad=$ Frequency

$\mathrm{d} \quad=$ Jarak

$\mathrm{W} \quad=$ Lebar jalan

$\mathrm{b} \quad=$ Jarak antara bangunan di seberangnya

$\mathrm{hm} \quad=$ Tinggi MS (Mobile Station)

$\mathrm{hb} \quad=$ Tinggi BTS (Base Tranceiver Station) hroof = Tinggi halangan/Obstacle yang ada di sekitar BTS.

Tabel 4.Parameter Penelitian Pada Model Pathloss Walfisch Ikegami

\begin{tabular}{cccc}
\hline No & Notasi & Satuan & Nilai \\
\hline 1 & & & 37 (Urban) \\
& $\mathrm{Hb}$ & Meter $(\mathrm{m})$ & 65 (Sub-Urban) \\
68 (Rural) & & 1,5 \\
2 & & Meter $(\mathrm{m})$ & 35,2 \\
3 & $\mathrm{Hm}$ & Meter $(\mathrm{m})$ & 7 \\
4 & $\Delta \mathrm{hm}$ & Meter $(\mathrm{m})$ & 1800 \\
5 & $\Delta \mathrm{hb}$ & Mhz & 30 \\
6 & $\mathrm{Fc}$ & Meter $(\mathrm{m})$ & $0,1-2$ \\
7 & $\mathrm{Hroof}$ & Kilometer & 10 \\
8 & $\mathrm{~d}$ & Km) & 60 \\
9 & $\mathrm{~W}$ & Meter $(\mathrm{m})$ & \\
\hline
\end{tabular}

E. Perbandingan Pathloss Pengukuran dengan Pemodelan Pathloss

Data daya terima pengukuran yang telah didapatkan akan dikelompokkan sesuai cluster yag mewakilinya akan diolah kembali untuk menghitung nilai pathloss yang terjadi pada masing-masing cluster. Nilai pathloss didapatkan dengan menggunakan persamaan (17) [12].

$\mathrm{Pl}(\mathrm{dB})=\mathrm{Pt}(\mathrm{dBm})-\operatorname{Pr}(\mathrm{dBm})$

Dimana:

Pl adalah nilai pathloss

Pt adalah nilai daya pancar transmiter yaitu $43 \mathrm{dBm}$ [13]

Pr merupakan Daya terima data pengukuran $0,1 \mathrm{~km}$ sampai $2 \mathrm{~km}$ dengan metode drive test.

Perbandingan pathloss pengukuran terhadap pathloss COST-231 Hata dan pathloss Walfisch Ikegami dapat dianalisis dengan mengamati grafik pathloss dan nilai MSE (Mean Squared Error) dari tiap-tiap pemodelan pathloss terhadap pathloss Pengukuran. Nilai MSE dapat diperoleh dengan persamaan (18) [10] [14] [15][16].

$M S E=\sqrt{\frac{\sum_{i=1}^{N}\left(P_{m}-P_{r}\right)^{2}}{N-1}}$

\footnotetext{
Dimana:

$\mathrm{P}_{\mathrm{m}} \quad=$ Nilai Pathloss Pemodelan

$\mathrm{P}_{\mathrm{r}} \quad=$ Nilai Pathloss Pengukuran

$\mathrm{N} \quad=$ Banyaknya data sampling pengukuran
} 


\section{HASIL DAN PEMBAHASAN}

A. Hasil Pengukuran Daya Terima dengan Drive Test

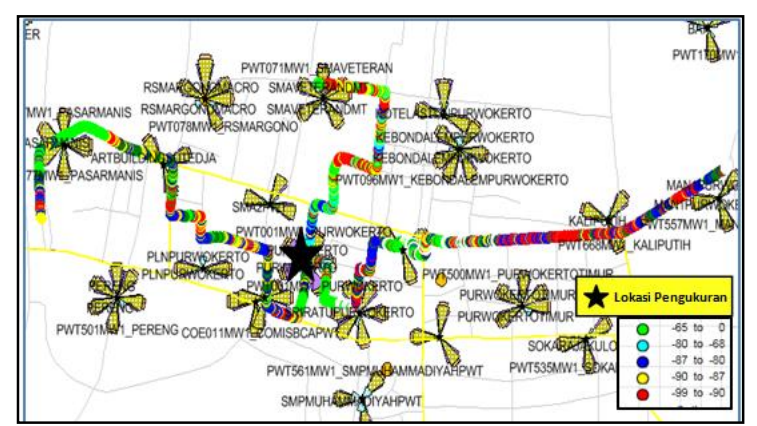

Gambar 5. Pemetaan Pengukuran Daya Terima Dengan Metode Drive Test di Cluster Urban

Gambar 5 merupakan hasil pemetaan pengukuran daya terima dengan metode drive test pada cluster urban di area Purwokerto.

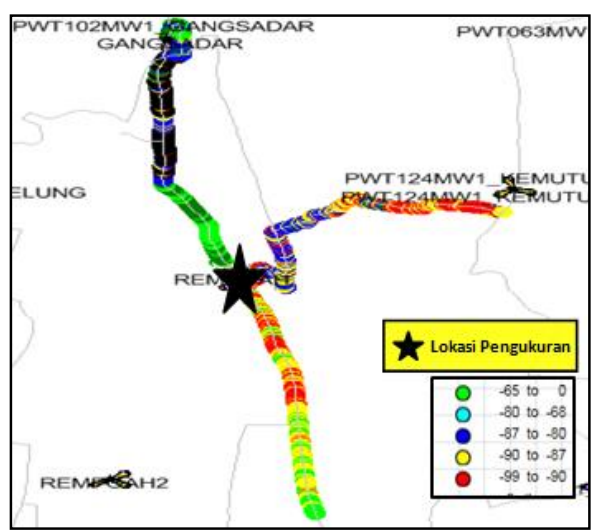

Gambar 6. Pemetaan Pengukuran Daya Terima Dengan Metode Drive Test di Cluster Sub-Urban

Gambar 6 menunjukkan hasil pemetaan pengukuran daya terima dengan metode drive test pada cluster Sub-Urban di area Rempoah. Jenis Drive test yang dilakukan adalah drive test SSV (Single Site Verification) dimana pengukuran hanya dilakukan pada jaringan satu site tersebut saja.

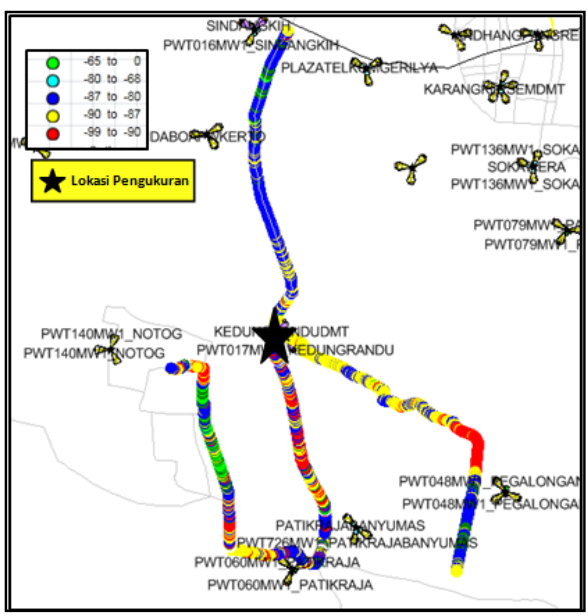

Gambar 7.Pemetaan Pengukuran Daya Terima Dengan Metode Drive Test di Cluster Rural
Gambar 7 merupakan hasil pemetaan pengukuran daya terima dengan metode drive test pada cluster rural di daerah Kedungrandu Banyumas.

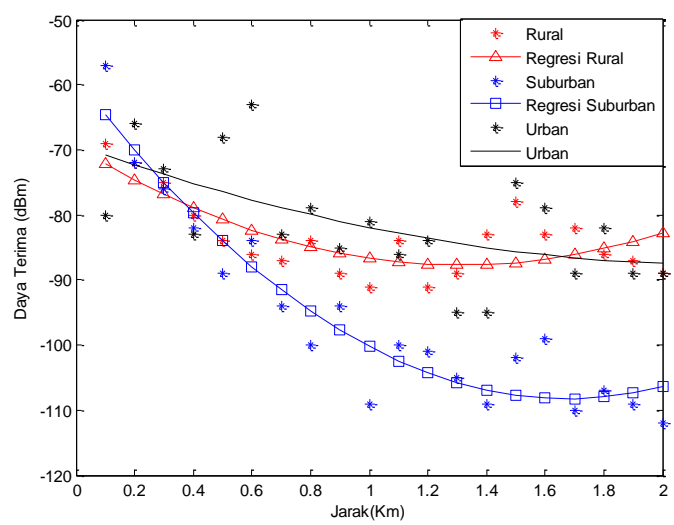

Gambar 8. Hasil Pengukuran Daya Terima

Hasil pengukuran daya terima dengan metode drive test kemudian diolah untuk memperoleh nilai daya terima dari $0,1 \mathrm{~km}$ sampai dengan $2 \mathrm{~km}$ seperti pada Gambar 8.

\section{B. Analisis Perbandingan Pathloss Pengukuran} Terhadap Pathlos COST-231 Hata dan Pathloss Walfisch Ikegami

Analisis perbandingan pathloss pengukuran terhadap pathloss COST-231 Hata dan pathloss Walfisch Ikegami dapat dilakukan dengan mengamati grafik pathloss dan nilai MSE (Mean Squared Error) dari tiap-tiap pemodelan pathloss terhadap pathloss pengukuran.

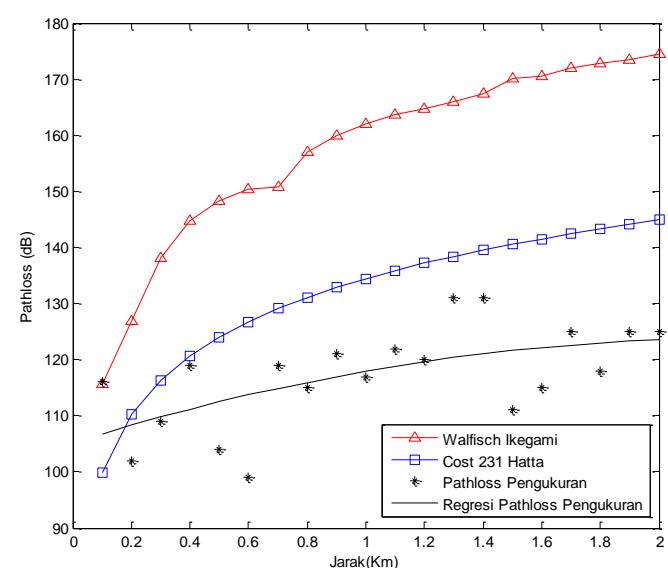

Gambar 9. Grafik Perbandingan Pathloss Pada Cluster Urban

Pada Gambar 9 terdapat tiga grafik yang diamati antara lain grafik pemodelan pathloss Walfisch Ikegami, grafik pemodelan pathloss COST-231 Hata dan grafik pathloss pengukuran beserta regresinya. Pada daerah urban pemodelan pathloss walfisch Ikegami memiliki nilai pathloss lebih tinggi dibandingkan dengan pemodelan pathloss COST-231 Hata dan pathloss pengukuran pada jarak $0,1 \mathrm{~km}$ maupun sampai dengan jarak $2 \mathrm{~km}$, sedangkan nilai 
Pathloss COST-231 Hatta memiliki nilai lebih besar dari pathloss pengukuran pada jarak $0,2 \mathrm{~km}$ sampai 2 $\mathrm{km}$. Berdasarkan grafik perbandingan pathloss di atas, grafik pathloss COST-231 Hata mendekati pathloss pengukuran di daerah urban, selain itu dari perhitungan nilai MSE dari persamaan 14 nilai MSE untuk pemodelan pathloss COST-231 memiliki nilai 18,16 dB, nilai ini lebih kecil jika dibandingkan dengan nilai MSE pemodelan pathloss Walfisch Ikegami yang sebesar 43,47 dB. Dari perbandingan grafik maupun nilai MSE tersebut pada daerah Urban pemodelan pathloss yang cocok adalah pemodelan pathloss COST-231 Hata.

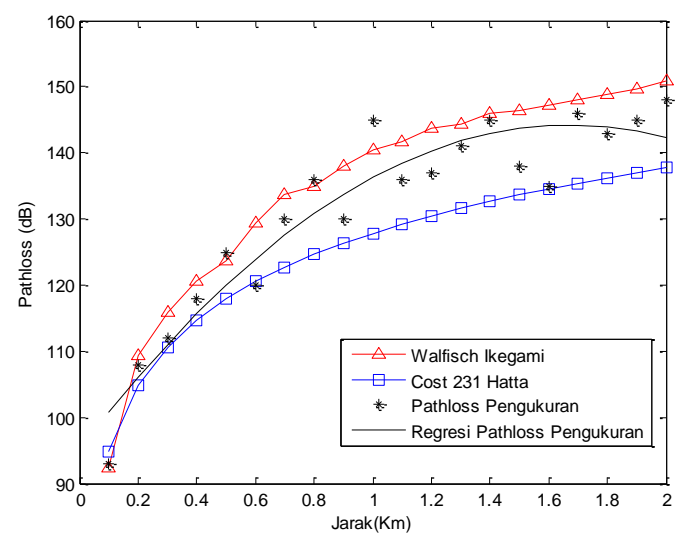

Gambar 10. Grafik Perbandingan Pathloss Pada Cluster SubUrban

Pada perbandingan pathloss di daerah Sub-Urban dapat dilihat pada Gambar 10, dari gambar tersebut dapat dilihat bahwa grafik pathloss pengukuran berada diantara grafik pathloss pemodelan Walfisch Ikegami dan pathloss pemodelan COST-231 Hata, tetapi grafik pathloss pengukuran lebih condong mendekati pemodelan Walfisch Ikegami, hal ini juga dapat dianalisa dari nilai MSE pathloss Walfisch Ikegami pada Tabel 5 yaitu sebesar 5,58 dB, nilai lebih kecil dibandingkan nilai MSE pathloss COST-231 Hata yang sebesar 8,91 dB. Berdasarkan analisis tersebut pada cluster Sub-Urban di daerah Banyumas pemodelan pathloss yang sesuai adalah pemodelan pathloss Walfisch Ikegami.

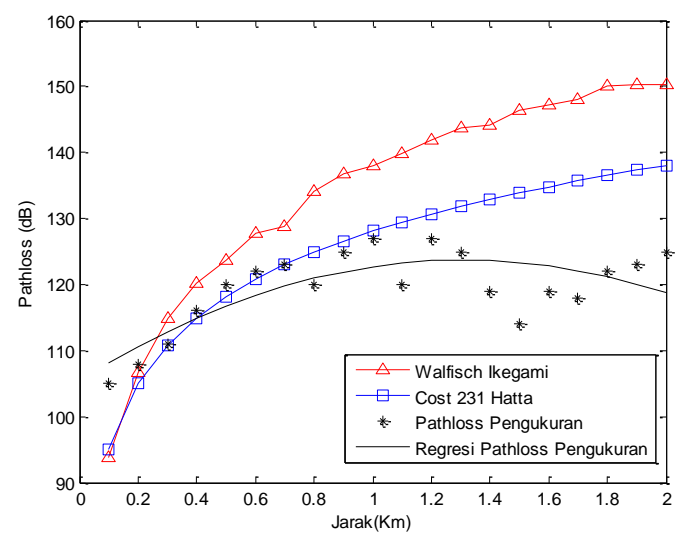

Gambar 11. Grafik Perbandingan Pathloss Pada Cluster Rural
Analisis perbandingan pathloss pengukuran pada daerah Rural dapat dilihat pada Gambar 11. Dari gambar tersebut dapat dianalisis pada grafik pathloss pengukuran daerah rural memiliki kecenderungan mendekati grafik pemodelan pathloss COST-231 Hata, hal ini dapat dianalisa pula dari nilai MSE dari kedua pemodelan tersebut pada Tabel 5. Berdasarkan nilai MSE kedua pemodelan dapat dianalisis nilai MSE COST-231 Hata memiliki nilai 10,33dB. Nilai ini lebih kecil jika dibandingkan dengan nilai MSE dari pemodelan pathloss Walfisch Ikegami yaitu sebesar $19,48 \mathrm{~dB}$, sehingga pemodelan pathloss yang sesuai maupun mendekati pada daerah rural adalah pemodelan pathloss COST-231 Hata.

Tabel 5.Hasil MSE (Mean Square Error) Perbandingan Pathloss Pengukuran dengan Pathloss Pemodelan

\begin{tabular}{ccc}
\hline & \multicolumn{2}{c}{$\begin{array}{c}\text { MSE (Mean Square Error) Pathloss } \\
\text { Pemodelan Terhadap Pathloss }\end{array}$} \\
\cline { 2 - 3 } & $\begin{array}{c}\text { COST-231 Hata } \\
(\mathbf{d B})\end{array}$ & $\begin{array}{c}\text { Walfisch Ikegami } \\
(\mathbf{d B})\end{array}$ \\
\hline Urban & 18,16 & 43,47 \\
$\begin{array}{c}\text { Sub- } \\
\text { Urban }\end{array}$ & 8,91 & 5,58 \\
Rural & 10,33 & 19,48 \\
\hline
\end{tabular}

Pada Tabel 5 ditunjukkan perbandingan nilai MSE dari tiap pemodelan pathloss pada cluster Urban, SubUrban dan rural. Pada cluster Urban dan Rural pemodelan pathloss COST-231 Hata memiliki nilai MSE 18,16 dB dan 10,33 dB, nilai ini lebih kecil dibandingkan Nilai MSE Walfisch Ikegami yaitu 43,47 dB dan 19,48 dB, hal ini menunjukkan pada cluster Urban dan Rural mempunyai kesesuaian pada pemodelan pathloss COST-231 Hata. Sedangkan pada cluster Sub-Urban nilai pemodelan pathloss Walfisch Ikegami adalah 5,58 dB, nilai ini lebih kecil jika dibandingkan pada nilai MSE pemodelan pathloss COST-231 Hata, hal ini menunjukkan pada cluster Sub-Urban mempunyai kesesuaian pada pemodelan pathloss Walfisch Ikegami.

\section{PENUTUP}

\section{A. Kesimpulan}

Pada analisis perbandingan pemodelan pathloss pengukuran dengan metode drivetest terhadap pemodelan pathloss COST-231 Hata dan Walfish Ikegami di wilayah Banyumas diperoleh pemodelan pathloss COST-231 cluster Urban dan Rural mempunyai kesesuaian dengan pathloss pengukuran dengan nilai MSE adalah 18,16 dB dan 10,33 dB, nilai tersebut lebih kecil dibandingkan dengan nilai MSE pada pemodelan pathloss Walfisch Ikegami, Sedangkan pada cluster Sub-Urban mempunyai kesesuaian dengan pathloss Walfisch Ikegami dengan nilai MSE 5,58 dB. 


\section{DAFTAR PUSTAKA}

[1] Olasunkanmi Fatai Oseni, Segun Isaiah Popoola, "Empirical Path Loss Models for GSM Network Deployment in Makurdi, Nigeria," International Refereed Journal of Engineering and Science (IRJES), vol. 3, no. 6, pp. 85-94, Juni 2014.

[2] Dongya Shen, Yonggang Xie, Xiangde Li Yihuai Yung, "MATLAB Simulink of COST 231 - WI Model," International Journal of Wireless and Microwave Technologies, vol. 3, pp. 1-8, Juni 2012.

[3] Yuvraj Singh, "Comparison of Okumura, Hata and COST-231 Models on the Basis of Path Loss and Signal Strength," International Journal of Computer Applications, vol. 59, no. 11, pp. 37-41, Desember 2012.

[4] Premchandra Kumar, Bhushan Patil, and Suraj Ram, "Selection of Radio Propagation Model for Long Term Evolution (LTE) Network," International Journal of Engineering Research and General Science, vol. 3, no. 1, pp. 373-379, January-February 2015.

[5] A.N. Jadhav Sachin S. Kale, "An Empirically Based Path Loss Models for LTE Advanced Network and Modeling for 4G Wireless Systems at $2.4 \mathrm{GHz}, 2.6$ $\mathrm{GHz}$ and $3.5 \mathrm{GHz}, "$ International Journal of Application or Innovation in Engineering \& Management (IJAIEM), vol. 2, no. 9, pp. $252-257$, September 2013.

[6] Parveen Kumar, Shashi B. Rana Pardeep Pathania, "Performance Evaluation of different Path Loss Models for Broadcasting applications," American Journal of Engineering Research (AJER), vol. 03, no. 04, pp. 335-342, 2014.

[7] Fakhruddin Ahmad NST, Delsina Faiza, and Khairi Budayawan, "Analisis Model Propagasi Komunikasi Bergerak pada Sistem GSM di PT. Xl AXIATA Padang," Jurnal Vokasional Teknik Elektronika \& Informatika, vol. 4, pp. 11-21, Januari-Juni 2016.

[8] Pratibha Maina,Gopal Chandra Manna, Namrata Sahayam, "Validation Study Of Path Loss Models On Wimax At 2.6 Ghz Frequency Band In Sub-Urban Environment For Cell Size Planning," International Journal of Next-Generation Networks (IJNGN), vol. 6, pp. 17-29, Juni 2014.
[9] Akujobi Ekeocha, Nosiri Onyebuchi, Achumba Ifenyinwa, "Comparative Study of Path Loss Models for Wireless Communication in Urban and Sub-urban Environment for Port Harcourt, Nigeria," American Journal of Engineering Research (AJER), vol. 4, no. 11, pp. 109-115, 2015.

[10] Esobinenwu C B.O.H Akinwole, "Adjustment of Cost 231 Hata Path Model For Cellular Transmission in Rivers State," IOSR Journal of Electrical and Electronics Engineering (IOSR-JEEE), vol. 6, no. 5, pp. 16-23, Juli- Agustus 2013.

[11] Andreas F. Molisch, Wireless Communications, Second Edition, 2nd ed.: A John Wiley and Sons, Ltd., Publication, 2011.

[12] Musa Ahmed, Tonga A. Danladi Dominic S. Nyitamen, "Path Loss Propagation Model Prediction For Gsm Mobile Network Planning In Kaduna Town," International Journal of Engineering Sciences \& Research Technology, vol. 4, no. 4, pp. 345-352, April 2015.

[13] Jiri Hosek, Jiri Misurec Yahia Zakaria, "Path Loss Measurements for Wireless Communication in Urban and Rural Environments ," American Journal of Engineering and Applied Sciences, no. 1, pp. 94-99, Agustus 2015.

[14] Muntaqo Alfin Amanaf, Eko Setijadi, and Suwadi, "Implementasi Sistem Akuisisi Data pada Bridge Sructural Health Monitoring dengan Jaringan Sensor Nirkabel," in Proceeding Seminar Ilmu Pengetahuan Teknik 2013, Yogyakarta, 2013, pp. 428-432.

[15] R.K.Singh Purnima K. Sharma, "Propagation Path Loss Measurements and Spline Interpolation for Missing Data," International Journal of Mobile \& Adhoc Network|, vol. 2, no. 1, pp. 68-72, Februari 2012.

[16] Eko Setijadi, Muntaqo A.A, Suwadi , and Slamet BP, "Design of Large Scale Structural Health Monitoring System for Long-Span Bridges Based on Wireless Sensor Network," in International Joint Conference on Awareness Science and Technology and Ubi-Media Computing (iCAST-UMEDIA), Aizu Wakamatsu, 2013, pp. 169-173. 